\title{
Mandala Desenlerinden İslami Süslemelere Dairesel Örüntüler ve Çağdaş Sanata Yansımaları
}

\section{Circular Patterns; From Mandala Drawings to Islamic Ornaments and Their Reflections on Contemporary Art}

\section{Hatice Doğan}

Dr. Öğr. Üyesi, Atatürk Üniversitesi, Güzel Sanatlar Fakültesi, Resim Bölümü email: haticeedogan@gmail.com DORCID ID: https://orcid.org/0000-0003-4301-1677

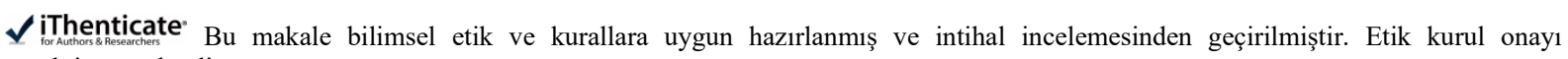
gerektirmemektedir.
\end{abstract}

Atıf (APA 7)/To cite this article

Doğan, H. (2021). Mandala desenlerinden İslami süslemelere dairesel örüntüler ve çağdaş sanata yansımaları. Atatürk Üniversitesi Güzel Sanatlar Enstitüsü Dergisi, 27(47), 463-479. doi: https://doi.org/10.35247/ataunigsed.912612

Makale Gönderim Tarihi/Received: 09/04/2021

Makale Kabul Tarihi/Accepted: 09/09/2021

Makale Yayın Tarihi/Published: 28/10/2021

Review Article / Derleme Makale

\section{$\ddot{\mathbf{O z}}$}

Daire insan hayatında en ilksel bir biçim olarak var olmuştur. İnsan türü dünya üzerindeki var oluşunun erken döneminde gökyüzüne baktığında karșılaștığı ilk form daireseldir. Bu yüzden dairenin insan için bilinçdışında arketipsel bir form olduğu söylenebilir. Dairesel örüntüler ise bir merkez etrafında aynı biçimin tekrar etmesiyle oluşturulur ve tarih boyunca çeşitli kültürlerde karşımıza çıkar. Bu örüntüler çoğu inanç sisteminde insanoğlunun dünyanın anlamsızlı̆̆ına ve korkutuculuğuna karșı güvenebileceği tek nokta olan Tanrı'yı sembolize ederler. Bu özelliğinden dolayı dairesel örüntüler birçok çağdaş sanatçı tarafından çeşitli duygusal ve bilişsel durumları aktarmak için eserlerinde kullanılmaktadır.

$\mathrm{Bu}$ çalışmada dairesel örüntülerin ortaya çıkışı, çeşitli inanç sistemlerinde merkez sembolizminin varlığı ortaya konacak ve çağdaş sanatçıların eserlerinde dairesel örüntüleri kullanma biçimleri tartışılacaktır.

Anahtar kelimeler: Daire, Örüntü, Mandala, İslami Desenler, Çağdaş Sanat

\begin{abstract}
A circle is the most primordial form in human life. In the early ages of the human race, he met firstly circular forms when looking up to the sky. So circle became an archetypal form for humans unconsciously. Circular patterns which emerge from the repetition of the same forms in order and are shaped around a center appear in different forms in various cultures throughout human history. And in most belief systems they are the symbols of God, which is the only meaningful point that people can rely on, despite the meaninglessness and horror in the world. Therefore, many contemporary artists use that symbolism in their works to express various emotional and cognitive states.

In this study, the emergence of circular patterns, how center symbolism exists in various beliefs will be revealed and the ways contemporary artists use circular patterns in their works will be discussed.
\end{abstract}

Keywords: Circle, Pattern, Mandala, Islamic Ornaments, Contemporary Art

\section{Giriş}

Dünyayı anlama ve böylece onunla ilgili korkularından kurtulma arayışındaki insan, bu amaçla çok çeşitli inançlar ve bu inançları görselleştiren imgeler yaratmıştır. Wilhelm Worringer'e göre insanın imge yaratmasında iki tür temel yönelim vardır. Bunlardan biri evrenle ilgili korkularının üstesinden gelmek için doğayı taklit ederek, o korkuyu yaratan güç ile özdeşleşim kurmaktır. Diğer yandan Worringer'in "soyutlama içtepisi” adını verdiği durumda ise insan bu güçten kendini tamamen soyutlayarak, doğada olmayan inorganik formlar ortaya koymuştur. Bu iki yönelim Batı sanatı ve Doğu sanatını da birbirinden ayıran en önemli farklardan biridir. Batı sanatı görünür dünyanın yansımalarını üretirken, Doğu sanatı daha sembolik ve geometrik biçimleri üreten bir yönde gelişim göstermiştir:

Bir piramidin cansız biçimini ya da örneğin Bizans mozaiklerinde kendini gösteren hayatın ortadan kaldırılışını anımsayalım; bunlar, kesin bir dille şunu ifade eder: Burada, anlaşılması kolay nedenlerden ötürü, daima organik olana eğilimli olan özdeşleyim ihtiyacının sanat istemini belirleyebilmiş olması imkansızdır. Hatta burada özdeşleyim içtepisinin doğrudan doğruya karşıtı olan ve özdeşleyim içtepisini tatmin eden şeyleri ortadan kaldırmaya çalışan bir içtepinin olduğunu kabul etmek zorundayız (Worringer, 2017, s. 24).

Kutsal sanatın işlevi, belli bir inanca sahip insanların bu inançlarını doğrulamak, manevi yaşamlarına, ruhsal olarak daha iyi bir duruma gelmelerine destek sağlamak, "insanlara dünyayı ve ardında yatan hakikatleri kavrama yolunu” göstermektir (Sutton, 2019, s. 7). Bu hakikatleri anlamak için insan kendisini kuşatan dünyada bu hakikate dair işaretler arayacaktır. Kutsal sanatta kullanılan geometrik formlar inanan insana bu işaretleri sağlar. Bu geometrik formlar arasında dairenin ve daireden türetilen geometrik örüntülerin simgesel olarak kullanımına hem 
Doğu hem Batı kutsal sanatında sıkça rastlanmaktadır. Kutsal sanatın sanat tarihinin her dönemde etkilediği ve yön verdiği din dışı sanatta da geometrik süsleme anlayışının yansımaları göze çarpmaktadır.

\section{Yöntem}

$\mathrm{Bu}$ araştırma betimsel modele dayalı nitel bir araştırmadır. Çağdaş sanatta dairesel örüntülerin kullanımının simgesel kökenlerinin izini sürebilmek amacıyla önce daire formunun sembolik anlamı üzerinde durulmuş, daha sonra çeşitli inanç ve kültürlerde dairesel örüntülerin kullanımı ortaya konulmaya çalışılmıştır. Bu kullanımlardan biri olarak ön plana çıkan mandala formunun sembolik anlamı ve mandala desenlerini psikanalitik açıdan değerlendiren Carl Gustav Jung'un bireyleşme kavramı üzerinde durulacak ve son bölümde daire formunun ve özelde mandala biçimini sanat üretimlerinde kullanan bazı çağdaş sanatçıların eserlerine yer verilecektir.

\section{Bulgular ve Yorum}

\subsection{Daire}

Dairenin geometrik şekiller arasında en temel şekil olduğu söylenebilir. Doğada bulunan desenler arasında diğer geometrik şekiller nadiren bulunur. Üçgen ve dörtgenler daha çok insan tarafından sonradan üretilmiş yapılarda karşımıza çıkarken, daireler doğal ortamda sıkça karşılaştığımız biçimlerdir. Bu yüzden daire biçimi, doğa ile ilişsisinde ilk karşılaştığı biçim olması ile arketipik bir sembol olarak insanoğlunun zihninde yer etmiştir.

Gök cisimlerinin yuvarlak olması onların şekillerine uygun olarak dairesel biçimde hareket ettikleri fikrini doğurmuştur. İnsan zihni en basit şekillerin en temel şekiller olduğu algısına sahiptir. Bu anlamda daire de en basit doğal şekil olarak kabul edilegelmiştir (Arnheim, 2012, s. 308).

Daire birliği, tamamlanmışlığı, sonsuzluğu ve kusursuzluğu hissettirir. Dolayısıyla düzenle, kozmozla, ve başlangıcı-sonu olmayan bir Tanrı düşüncesi ile ilişkilendirilmiştir. Kozmozla bağlantılı olarak, daire bir merkezin etrafında hareketi ve merkezden çevreye doğru genişlemeyi, hiçliği, boşluğu, sonsuzluğu ve sınırsızlığı akla getirdiği gibi, bazı şeyleri kapsarken diğerlerini dışarıda bırakabilecek sınırlayıcı bir alan da yaratabilir. Hayatı yöneten döngülerden hareketle, değişim daire biçimi ile simgelenir. Aynı zamanda daire çeşitli inançlarda insan ruhu ile de ilişkilendirilmiştir. Daire biçimine, bütün bu ilişkilendirmeler doğrultusunda hemen hemen bütün inanç sistemlerinde rastlanır: Hint ve Budist mandalaları, cami kubbeleri, Hristiyan katedrallerinin gül pencereleri gibi.

"Daire motifi ortaya çıktığı her yerde, eski güneş inançlarında ya da çağdaş dinsel görüntülerde, mit ya da düşlerde, meditasyon resimlerinde ya da modern kentlerin planlarında, daima yaşamın bir yönüne, temelindeki bütünlüğe işaret eder" (Jung, 2009, s. 240). Küre imgesi fiziksel, biyolojik ve felsefi fenomenleri betimlemek için yüzyıllar boyu kullanılmıştır. "Yuvarlaklık, şekli olmayan, belirli bir şekli olmayan ya da bütün şekillere sahip bir şeyi temsil etmek için kendiliğinden ve evrensel olarak seçilmiştir”. Parmenides, dünyanın bütünlüğünü ve tamlığını bir küreyle göstermiştir (Arnheim, 2012, s. 311).

Bir daire ve onunla kesişen başka dairelerle diğer geometrik şekiller oluşturulabilir. Bu da dairenin sahip olduğu sonsuz potansiyeli gösterir. $\mathrm{Bu}$ durum İslam sanatında var olan tekrarlayan geometrik süslemelerin temel prensibini oluşturmaktadır. Daire sonsuzluk simgesi olması ile gökyüzünü temsil ederken kare yeryüzünü simgeler. Hinduizm ve Budizm'de kullanılan mandala formunda da daire ve kare formu birlikte kullanılmaktadır (Ögel, 1994, s. 95-96).

Dini yapılarda dikkat çeken, dairesel biçim kozmik hareketliliği gösterirken, dikdörtgen veya kare biçim, değişmez kanunları simgeler. Bir anlamda daire gökyüzü ile, kare ise yeryüzü ile ilgilidir (Burckhardt, 2017, s. 23). Daire ve kare arasındaki bu zıtlık göçebe ve yerleşik halklar arasındaki zıtlıkta yansımasını bulmaktadır. "Göçebe halklar ideallerini dairenin hareketli ve sınırsız tabiatında görürken yerleşik halklar ideallerini karenin hareketsiz karakterinde ve düzenliliğinde görür" (Burckhardt, 2017, s. 29). Örneğin göçebe Türklerde dairesel biçimdeki çadır kozmozun simgesi olarak görülmüştür. İslami düşünürler kâinat anlayışlarını iç içe geçmiş konsentrik dairelerle ifade etmişlerdir. Bu dairelerin merkezinde evrensel akıl bulunur. Bu düşünce Anadolu Selçuklu mimari süslemelerinde yansımasını bulmuştur (Peker, 1998, s. 35).

\subsection{Merkez Sembolizmi}

Dairenin sınırları ve merkez arasındaki ilişki genellikle kürenin ya da dairenin merkezden doğup geliştiği ve merkezin kontrol edici nokta olduğu varsayımı ile ifade edilir. $\mathrm{Bu}$ varsayım Kepler'in görüşüdür. Kepler bu görüşten hareketle gezegenler sisteminin merkezdeki güneşten kaynaklandığını ve enerjilerini buradan aldıklarını kabul eder. Daire ve merkezi arasındaki ilişki en büyük ve en küçük arasındaki ilişkiyi örneklemek için de kullanılmıştır. Aquina'lı Thomas'a göre Tanrı, her şeyi kuşatan varlığıyla kürenin sınır yüzeyi; yaratıklar ise önemsizlikleri ile kürenin merkez noktası tarafından temsil edilirler. "17. yüzyıl Alman mistiklerinden Johannes Scheffler, ikisi arasında dinamik bir etkileşim tahayyül eder: İnsan Tanrı’yı kendi içine kapattığında dairesel sınır merkeze doğru daralır, bunun tersi de doğrudur, insan Tanrı'nın büyüklüğünde eridiğinde, merkez çevreye doğru yayılır" (Arnheim, 2012, s. 311-312). 


\section{Görsel 1}

Kepler'in Evren Modeli

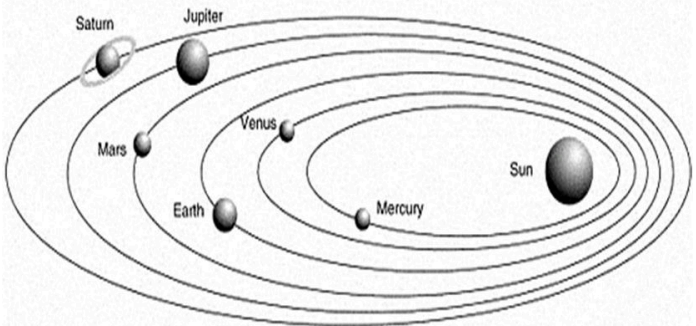

(Kepler, t.y.)

Eski toplumlarda dünya bir "mikro evren" dir. Bildikleri bu dünyanın dışında kalan alanda bilinmeyenlerle dolu ürkütücü bir alan vardır. Mikro evrene kendi içinde düzen hâkim iken bu bilinmeyen güçler tarafından düzenin bozulması eski kaos haline geri döndürme tehlikesi vardır. Diğer yandan bu mikro evrenin merkezinde kutsal ve tek olanın tezahür ettiği bir yer olduğu inancı hakimdir. Doğu uygarlıkları bu şekilde sınırsız sayıda "Merkez" kabul etmişler ve bunların hepsine de "Dünyanın Merkezi” adını vermişlerdir (Eliade, 2018, s. 48-51). Rene Guenon, “Alemin Hükümdarı” eserinde, “dünyanın hükümdarı” unvanının ilk olarak, çeşitli eski toplumlarda farklı adlarla anılan, kanun yapıcı "kozmik akıl" olarak inanılan Manu'ya ait olduğunu öne sürer. Hindu geleneğinde yer alan ve "tekeri döndüren” anlamına gelen "Şakravarti” kavramını da Manu inancıyla bağdaştırır. Şakravarti, her şeyin merkezinde yer alan, bizzat kendisi katılmadan hareketi yönlendiren, Aristo’ya göre "hareket etmeyen hareket ettirici"dir. Guenon'a göre bu merkez bütün geleneklerde "kutup" olarak tanımlanmış olan sabit noktadır ve genellikle bir teker ile gösterilir. Bu teker bazı kültürlerde Hristiyanlık'taki gül sembolizminde ya da Doğu kültürlerindeki lotus simgesi gibi çiçek biçimine girer. Guenon ayrıca hem Doğu hem Batı uygarlıklarında sık kullanılan svastika sembolünün de merkez-kutup sembolizmiyle bağlantılı olduğunu savunmaktadır. Buna göre svastika değişmeyen bir eksen etrafındaki hareketin sembolüdür (Guenon, 2004, s. 17-19).

\section{Görsel 2}

Farklı Kültürlerde Svastika Sembolü

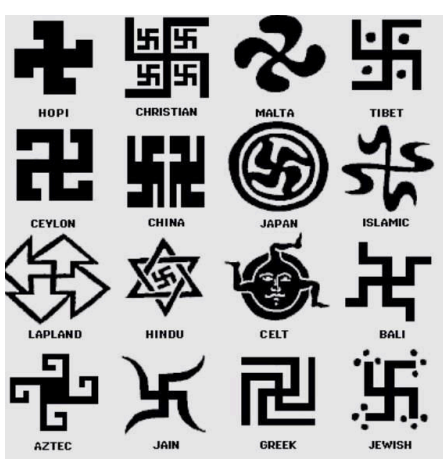

(Osmanca, 2018)

Daire ve merkezi arasındaki sembolik ilişki sadece dini yapıların planlarında değil içlerinde yer alan ve "inancı doğrulama" görevini yerine getiren süslemelerde de karşımıza çıkmaktadır. Özellikle geometrik süslemeler evrenin bir görüntüsünü sunmak bakımından yapı planlarına en çok destek veren elemanlardır. Geometrik süslemelerin kaynak aldığı geometrik biçimlerin hepsinin tarih boyunca kabul edilmiş belli anlamları vardır. Bu anlamları, Platon, kozmik yasalardan da bahsettiği Timaeus diyalogunda; Küp = yer, piramit $=$ ateş, üçgen prizma = hava, 12 yüzlü prizma $=$ kosmos, 20 yüzlü prizma $=$ su şeklinde ortaya koymuştur. Platon düşüncesine göre evrendeki her şey ölçülerle, matematik değerlerle ifade edilebilir niteliktedir. Bu yüzden matematik tanrısal bilgeliktir (Archer, 1888).

Burckhardt'a göre; tabiatın dönüşümlerden ibaret olduğunu ve kâinatın sürekli bir dairesel hareket içinde olduğunu anlayan insan, bu hareketin özü olan merkezi tanıyacaktır. Sanatın görevi de kâinatta var olan bu ritme uymak ve onu ifade etmektir. Bunun için en basit formül tek harekette bir daire çizmek ve kendini dairenin merkezi ile özdeşleştirmektir (Burckhardt, 2017, s. 13-14).

Merkez sembolizmi çeşitli kültürlerde bir merkez etrafında biçimlenen dairesel kompozisyonlar şeklinde karşımıza çıkar. Çin Tao öğretisinde yer alan Yin ve Yang 1 temsil eden dairesel biçim bunlardan biridir. Pasif, dişi, karanlık ve yeryüzünü sembolize eden siyah yarı ile, aktif, eril, aydınlık ve gökyüzünü sembolize eden beyaz yarı birleşerek kozmosu ve sonsuza dek devam eden yaşam döngüsüne işaret eden bir daire oluştururlar. Bu daire 
kozmosun ve içindeki her şeyin uyumunun dengeden geçtiğini hatırlatmaktadır. Yin Yang sembolü, Çin Zodyak sistemini temsil eden dairesel sembollerin de merkezinde bulunur. Merkezin etrafında her biri başka bir hayvana karşılık gelen Çin kaligrafi karakterleri bulunur (Gibson, 2017, s. 142-149).

\section{Görsel 3}

Çin Zodyak Sistemi

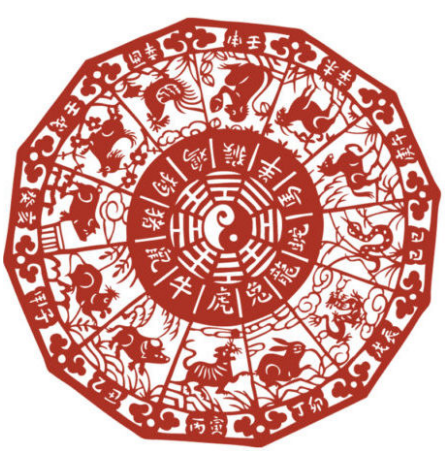

(Educating Humanity, 2012)

Tantra yantra özellikle Hint inancında yerini bulan, evreni ve onun kozmik bileșenlerini gösteren bir tür diyagramdır. Lotus yaprakları biçimindeki dış çemberler yaratılışa, varoluşun ve kâinatın sonsuz döngüsünü görselleştirirken içteki birbiriyle kesişen üçgenler erkekliği ve dişiliği, Diyagramın ortasındaki tek nokta ise merkezi ve mutlak olanı temsil eder (Gibson, 2017, s. 23).

\section{Görsel 4}

Tantra Yantra

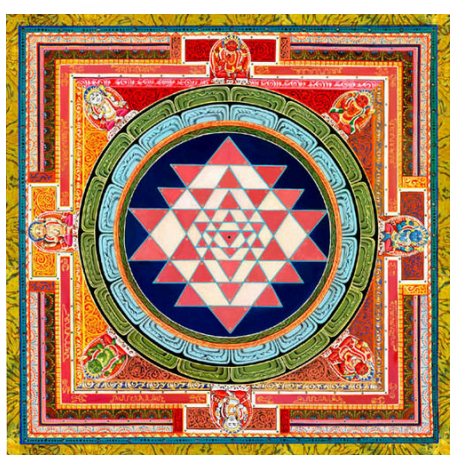

(Rudra Centre, t.y.)

Merkez sembolizminin başka bir örneği Aztek takvim taşlarında görülür. Aztek takvim taşı üzerine Meksika kozmogonisine ait semboller işlenmiştir. Semboller Azteklerde şiddetin, savaşın önemi, kozmik döngüler ve tanrılarla insanlar arasındaki ilişkilerle ilgilidir. Taşın merkezinde Aztek güneş tanrısı Tanatiuh vardır.

\section{Görsel 5}

Aztek Takvim Taşı

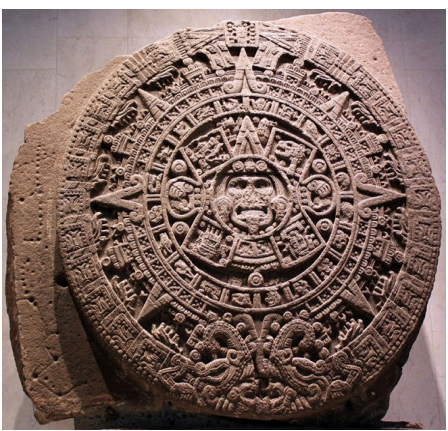

(Fonseca Mata, 2019)

Hristiyan inancının erken dönemlerinde, katakomblarda rastlanan ve Hz. İsa’yı evrenin merkezi olarak temsil eden çeşitli simgelerde merkez sembolizmine rastlanır. Aynı durum Hristiyan mimarisine de yansımıştır. Mimarinin 
hem genel yapısı hem de iç mimaride süsleme elemanı olarak kullanılan gül pencereleri merkez sembolizmini yansıtan niteliktedir. Gül pencerelerine Romanesk dönemde de rastlanmasına rağmen Gotik dönemde yaygınlaşmışlardır. "Bu camlardaki sembolizm çember (mükemmellik ve cennet, teker (sonsuzluk), kırmızı gül (sevgi ve din şehitliği) ve Meryem ana (lekelenmemiş “dikensiz gül”) temalarını birleştirir” (Gibson, 2017, s. 163). Birçok yazar, gül pencerelerini bir mandala simgesine benzer şekilde bütünlük ve tutarlılığa ulaşmanın bir ifadesi olarak yorumlamaktadır. Gül pencerelerinde yer alan detaylar inananlar için birçok mesaj içerir. Örneğin; Paris'teki Notre Dame Katedrali'nin kuzey gül penceresinde ağırlıklı olarak mavi ve kırmızı renkler kullanılmıştır. Mavi renk, Meryem Ana'nın saflığını akla getirirken, kırmızı, İsa Mesih'in kanını simgeler. Gül penceresinin ortasında Meryem Ana ve bebek İsa yer almaktadır. Meryem ve bebek İsa, güvercin ve melek figürleriyle çevrilmiştir. Bu figürler aynı zamanda İsa'nın gelişini de simgelemektedir. Melekleri ve güvercinleri çevreleyen çemberde ise Mesih'e tanıklık eden 12 büyük peygamberi gösteren figürler vardır (Wasatch Shutter Design, 2020).

\section{Görsel 6}

Notre Dame Katedrali Kuzey Gül Penceresi

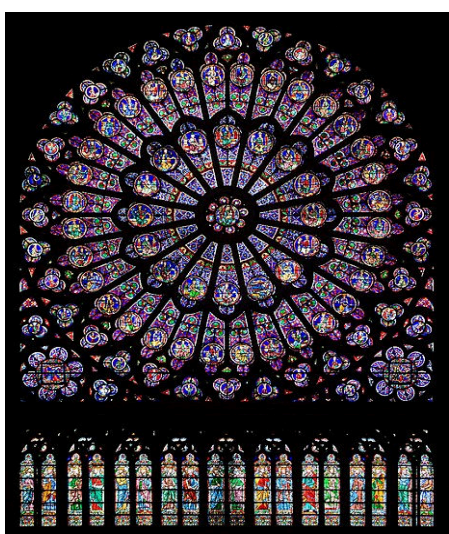

(Workman, 2010)

\subsection{Dairesel Örüntüler ve İslam Sanatı}

Daha aşağı olarak kabul edilenin daha yüce olana işaret etmesi hermenötik bir ön kabuldür. Bu açıdan, İslam dinine göre bir müslüman doğada gördüğü her şeye Allah'ın işareti gözüyle bakmalıdır. Çoğu kültürde dini mekanların "Tanrı'nın Evi" olduğu inancı hakimdir. Bu yüzden mabedler evrenin bir özeti gibi tasarlanır (Burckhardt, 2017, s. 21-22). Camiler de bu anlayışı hem mimari biçimleri ile hem de içerdikleri süslemelerle ortaya koyarlar. İslam mimarisinin İslam kozmolojisi ile yakın ilişkisi vardır. İslam mimarisinde cami kubbesinin merkezi Allah'ı ve ruhu temsil eder. Cami kubbesinin dayandığı, genellikle sekizgen olan kemer melekler makamını ve dörtgen de yeryüzünü ya da maddesel alemi temsil eder. İslâmi kozmos tüm varlıkların kökeni olarak Allah'a ve Allah'ın emriyle düzenlenmiş olan varoluş hiyerarşisine dayanmaktadır. İslam mimarisi bu hiyerarşinin somutlaşmış hali olarak düşünülebilir (Nasr, 2017, s. 61). Cami kubbeleri inanan izleyiciye çokluğun kaynak aldığ 1 "Bir'liği” ve kâinatta var olan düzeni hissettirmek için tasarlanmış geometrik süslemelerle bezenmiştir.

\section{Görsel 7}

Malatya Ulu Camii Kubbesi

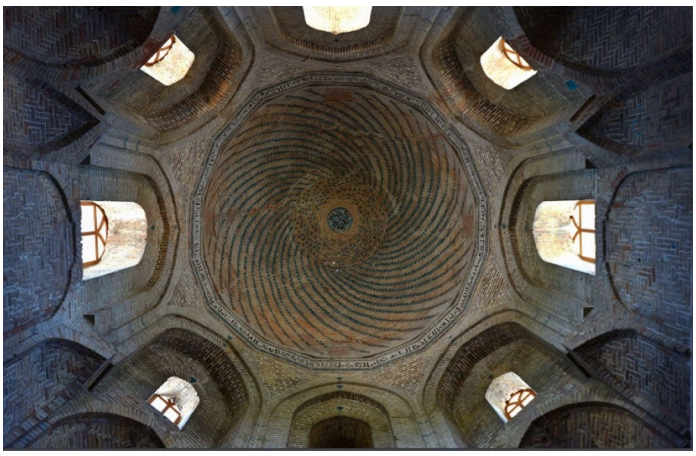

(Okur Yazarım, 2016)

İslami mimaride süsleme elemanı olarak kullanılan örüntüler, "cismanî varoluşun bâtınî yapısını" gösterirken, kendilerine bakan izleyiciye adeta kâinatın yapısını açar, kendisini çevreleyen "maddî olanı" anlayabilmesi için bir anahtar görevi görürler (Nasr, 2017, s. 72). İslami desenler kaligrafi ile stilize bitkisel formların birleşiminden oluşur. 
İslam hat sanatı, biçimlerinin sembolizmi aracıllğıyla, bizzat yaratılışı karakterize eden sabitlik ve değişme arasındaki kesişmeyi yansıtır. Dünya, sürekli bir akış ya da oluştan meydana gelmiştir; yine de bu oluş, İlâhî Kelime'de ya da akılda bulunan oluşun ve değişmez arketiplerin yansımasından başka bir şey değildir. İslâm hat sanatı, Kur'ân'ın metnini “cismanileştirerek” bizzat yaratılışın mahallini tekrar ettiği için bu metafiziksel hakikati yeniden yaratır (Nasr, 2017, s. 41).

"Hendeŝ̂" adı verilen geometrik örüntüler hat sanatına benzer şekilde insan zihninin bir üretimi olan soyut düzenlemelerdir. Hendese (geometri) ilminden kaynak almaları dolayısıyla ölçü ve simetriye dayanırlar. Tasvirden uzak durması gereken Müslüman sanatçılar çokluktaki birliği inançlarına uygun bir şekilde ifade etmenin yolunu geometride bulmuşlardır (Doğanay, 2012, s. 82). Bu geometrik kompozisyonları oluşturan motiflerin organizasyonu Semra Ögel tarafindan "yıldız sistemleri" olarak adlandırılmıștır. Yıldız sistemlerinde esas olan, daire ve içine çizilen temel geometrik şekillerin birbirleriyle kesişmeleridir. Ögel'e göre; Yıldız sistemlerinin organizasyonları kapalı geometrik şekillerden oluşsa da bir yıldızdan diğerine sürekli geçiş halinde olan doğrusal hareket vardır. Yıldızları oluşturan ışılların hiçbiri kapalı değildir. Bir yıldızdan diğerine, sonsuza dek devam eder gibi görünen sürekli bir geçiş vardır. Bu sürekli hareket, desenlerin üretilme sebebi olan "Çokluktaki birliğin" ifade edilmesini sağlar. Merkezin etrafinda dönüş duygusu veren tekrarlayan dairesel yıldızlar, evrendeki dairesel dönme hareketinin bir ifadesi olan çarkıfelek desenini akla getirir (Ögel, 1994, s. 97).

\section{Görsel 8}

Isfahan Şah Camii Kubbesi

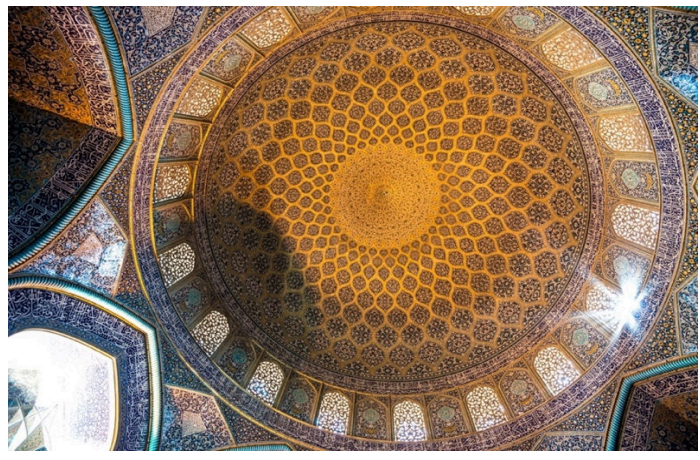

(Admin, 2021)

İslami geometrik örüntüler her zaman bir daire ile başlar ve daireye eşkenar üçgenler, kareler veya altıgenlerin eklenmesiyle oluşturulan bir sistemden türetilir. Bu sistemler için kullanılan matematiksel terim olan "regular tessellation" (düzenli mozaikleme), herhangi bir düzlemin kaplanması için bir çokgenin tekrarlaması anlamına gelir ve ismini Latin mozaiklerinden (tesserae) alımıştır. Oluşturulan tasarım ne kadar karmaşık veya girift olursa olsun, yine de tek bir sistemde gösterilebilir nitelik taşır. Geometrik süslemeler, uzaya doğru sınırsız bir şekilde genişleyebilir duygusu uyandırarak sonsuzluğu akla getirirler. (The Met, t.y.).

\section{Görsel 9}

\section{İslami Geometrik Desen Detayl}

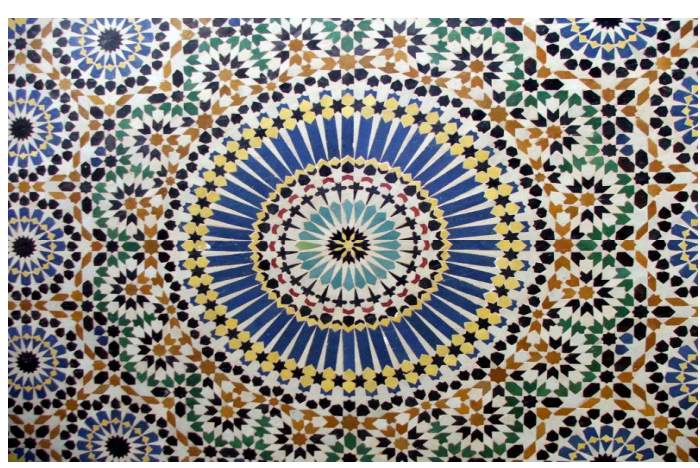

(Cooper, 2011)

\subsection{Mandala Desenleri}

Sanskritçe'de "daire" anlamına gelen "mandala" kelimesi, geometrik desenlerin çeşitli formlarda bir merkez etrafında ve bir düzen içerisinde tekrarlanmasıyla oluşturulan tasarımları anlatır. Tantra Hinduizmi ve Budizm'de bulunabilen mandala desenleri, kâğıt veya kumaş üzerine çeşitli malzemelerle yapılır ve meditasyon için kullanılır. Mandala deseni evreni gösterirken, desenin merkezi, evrendeki tüm kaosa rağmen insanın güvenebileceği tek sabit 
noktayı yani Tanrı'yı sembolize eder. Mandalalar tek bir temel örüntüden oluşturulurlar. Merkezde mutlak inancı temsil eden bir sembol vardır ve diğer çemberin çeşitli noktalarına yerleştirilmiş diğer semboller de aynı inancın çeşitli biçimlerini temsil eder. Mandalalarda görselleşen bu inancın temeli, tıpkı diğer kültürlerdeki dairesel örüntüler gibi, insanın evrenin sonsuz boşluğu karşısında hissettiği boşluk korkusu (horror vacuii) denilen dehşettir.

\section{Görsel 10}

Eski Bir Tibet Mandala Örneği

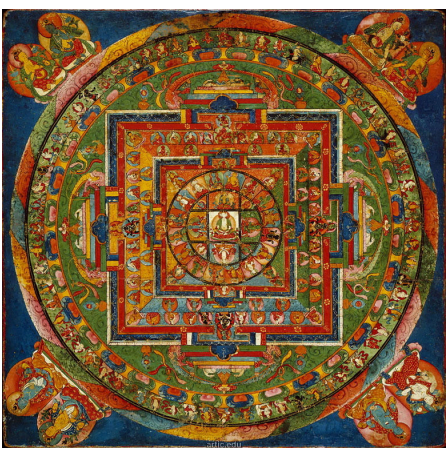

(Ancient Art Podcast, 2017)

Mandalalar, sadece eğitimli kişiler tarafından hayal gücü kullanılarak oluşturulabilen zihinsel imgelerdir. İki mandala hiçbir zaman birbirine benzemez (Jung, 2015, s. 194). Mandala desenini oluşturan kişi (mikrokozmos), düşünce yoluyla sembolik olarak mandalanın içine girer, "parçalanma" ve "yeniden bütünleşme" süreçlerinden geçerek, dünyanın (makrokozmos) görsel sembolizasyonu olan mandalanın merkezine doğru ilerler. Mandalaların görevi; İnanan kişinin kozmik gerçeklikle yeniden bütünleşerek kendisine, doğaya ve Tanrı'ya yabancılaşmasını aşmasını sağlamaktır. "Suunyataa" adı verilen mandalanın merkezi, spiritüel gerçekliği sembolize eden "praajna" ve "upaaya"nın birleşimidir. Bilgelik olan praajna pasif ve tepkisizdir, tanrıça ile sembolize edilir. Upaaya ise şefkattir, aktiftir ve erkektir. İkisinin birliği olan suunyataa uzayın ve zamanın fenomenal dünyasını yürüten sonsuz gerçekliktir ve evrenin beden ve ruh gibi tek olduğuna işaret eder. Bu teklik mandala deseninin ana fikridir. Mandalaların içerdiği bütün şekiller fenomenal dünyaya ait şeyleri, yani makrokozmik gerçekliği ve ruh ve bedenin nasıl iç içe geçtiğini sembolize eder (Cairns, 1962, s. 220-221).

Analitik psikolojinin kurucusu Carl Gustav Jung mandala desenini bir arketip olarak görmüştür. Jung’a göre merkezi olan bir daire çizimi Tanrı'nın doğası ile ilgili çok eskiden beri bilinen bir alegoridir (Jung, 2015, s. 207). Jung'un "merkezleştirme" dediği bireyleşme süreci rüyalarda mandala sembolizmini hatırlatan imgelerle ortaya çıkar. Mandalanın merkezi burada kendiliği sembolize eder. Jung hastalarının rüyalarında bu sembolizmi aramıştır. Jung aynı zamanda mandalanın merkezini rahimle ilişkilendirir;

Bütün durumlarda spiral, merkezi, dolayısıyla da rahmi vurgular ve Doğu mandalasının en temel anlamlarından biri olmasının yanı sıra simyadaki kabın da sıklıkla kullanılan bir eș anlamlısıdır...Rahim, merkez, yaşam- veren kaptır...Mandalanın merkezi Hint nilüferinin kadehine, tanrıların mevkisi ve doğum yerine tekabül eder, buna 'padma' denir ve dişil bir önemi vardır... Simyada 'vas' çocuğun taşındığı rahimdir. Hz. Meryem’den de ayinlerde 'vas’ olarak bahsedilir (Jung, 2015, s. 292-293).

Jung "Anima Mundi” (Dünyanın Ruhu) düşüncesini ve her şeyin etrafında döndüğü nokta olarak kutup düşüncesini de kendiliğin sembollerinden biri olarak görür ve ortak bilinçdışının sembolü olarak kabul eder (Jung, 2015, s. 302). Jung, mandalanın ortaya koyduğu deneyimin özellikle ilahi imgeyi artık yansıtamayan, bu yüzden de kişilik bölünmesi tehlikesi içerisinde olan insanlar için yararlı olduğunu ifade etmiştir. Mandaladaki kare veya yuvarlak çevrelerin kişilik bölünmesini önlemek amacıyla örülen duvarlar olarak kabul eder: "Böylelikle mandala, kişinin salt kendisi üzerinde yoğunlaşmasını söyler ve destekler. Bu durum egomerkezlilik dışında herşeydir. Tersine, şişmeden ve duygusal kopukluktan kaçınmak amacıyla çok gerek duyulan kendini (nefsi) kontrol mekanizmasıdır" (Jung, 2017, s. 78).

Jung'un analitik psikolojisinin amacı kolektif bilinçdışı ve ego nun benlik üzerindeki egemenliğinin bozulmasıdır. $\mathrm{Bu}$ da bir birey olma sürecinden geçerek gerçekleștirilir. Birey olma süreci mandala deseninde sembolize edilen yeniden bütünleşme süreci ile benzerdir. Jung'a göre acı ve arzunun egemenliğinden kurtulmak isteyen birey ilk olarak "gölge"nin varlığının farkına varmalıdır. Gölge, Jung'un tanımı ile, bireyin kolektif bilinç dışındaki arketiplerden biridir ve bireyin kendisinin de farkında olmadığı kontrolsüz, şiddete meyilli, karanlık tarafıdır.

Jung, birey olma sürecinin temelde bir dönüşüm süreci olduğunu söyler. Bu süreçte sorunun tanınması ve kabul edilmesi önemlidir. Doğu felsefesinde, insanın başlıca ahlaki kusurları, fenomenal kozmik bilinççışının durumlarından biri olarak kabul edilir. Bu kusurlar ve karşıtları olan iyi ahlaki özellikler mandalaların 
"sambhogakayaa" dairesinde temsil edilir. Benlik illüzyonu ve sebep olduğu tüm kötülüklerden kurtulma ruhun "merkez" denebilecek manevi boyutu ile bağlantı kurabilmesi sayesinde olur. Bu bağlantı ruhu sezgisel bir aydınlanma deneyimini yaşatır ve birey hem kendi benliği, hem diğer insanlar hem de kozmos ile yeniden bütünleşir (Cairns, 1962, s. 224). Bu anlamda Jung'un kendisi de hayatının bir döneminde tecrübe ettiği kendi benlik arayışı deneyimlerini Liber Novus (Kırmızı Kitap) isimli eserinde yazmış ve kendi ürettiği mandala desenleri de kitapta yer almıştır.

\section{Görsel 11}

Jung'un Mandala Çizimi

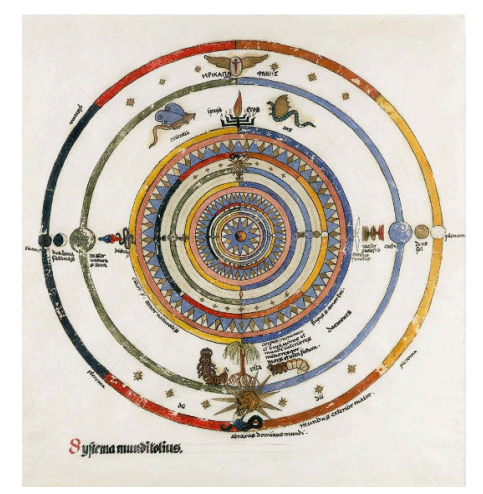

(Jung, 2019)

Mandala desenlerinde ve İslami geometrik desenlerde sembolize edilen, merkeze, tek ve nihai olana doğru ilerlemenin; Hz. Muhammed'in Mir'ac'a yükselmesi, Dante'nin İlahi Komedya'daki ruhani yolculuğu, Sufilerin "Eşref-i Mahlukat" olma yollarında ya da Hristiyan azizlerinin acılarla dolu hayat hikayelerindeki gibi çeşitli inanç sistemlerinde örnekleri görülür. Bu mistisizmin kaynağ1 ve dolayısıyla mandala benzeri görsel sembolizmin bu inançlardaki karşılığ 1 Neo Platonizm'dir. Neo Platonizm, MS. 205-270 yılları arasında yaşamış olan Plotinos tarafından geliştirilmiş bir düşüncedir. Plotin'e göre felsefenin nihai amacı, insanın kendinden vazgeçip ve Tanrı ile bir olmasıdır. Bu duygu ancak vecd ile yaşanabilir (Şenel, 2013, s. 423-427).

\section{5. Çă̆daş Sanatta Dairesel Örüntüler}

Birçok çağdaş sanatçı, dairesel formu ve dairesel örüntüleri farklı anlamlarda kullanmıştır. Bazı sanatçılar, kozmosu ve dolayısıyla sonsuzluğu akla getiren sembolizmiyle dairesel formu yeniden yorumlarken, bazı sanatçılar ise mandala deseninin manevi aydınlanmayı hedefleyen sembolizminden etkilenmiştir. Örneğin sürrealist sanatçı Max Ernst, "Galaksinin Doğuşu” adlı çalışmasında, merkezden kaynaklanan dairesel formlarla evrenin oluşumunu sembolik olarak göstermiştir. Eserde biçimler, Big Bang'in görsel yansıması olarak okunabilmesi için merkezden çemberin çevresine yayılmış şekilde gösterilmiştir.

\section{Görsel 12}

Max Ernst, Galaksinin Doğuşu, 1969

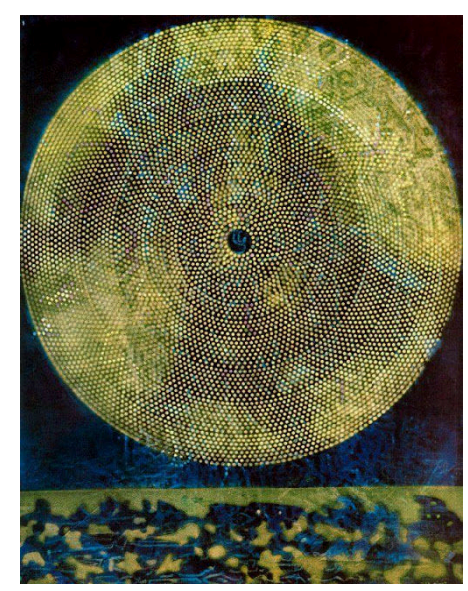

(Ernst, 1969) 
Dairesel biçim Op Art sanatçıları tarafından da sıklıkla kullanılmıştır. Bridget Riley eş merkezli zikzak dairelerle oluşturduğu "Blaze 1" adlı çalışmasında güneş ışı̆̆ının gözler üzerindeki etkisini görselleştirmek istemiştir. Zikzakların kullanılması ile dairesel formda merkeze doğru hareket algısı yaratılmıştır.

\section{Görsel 13}

Bridget Riley, Blaze1,1962

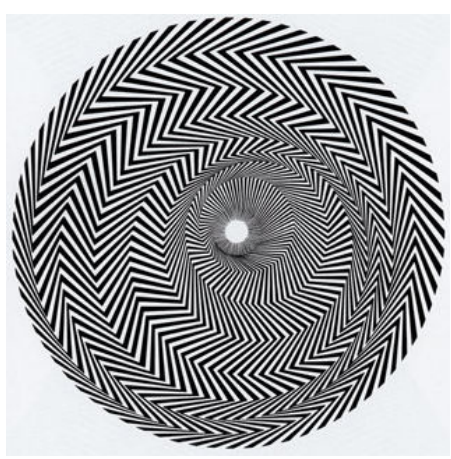

(Riley, 1962)

Eserlerinde farklı imgeleri, değișik tekniklerle bir araya getiren bir sanatçı olan Bill Armstrong'un "Infinity" başlıklı serisinin ana teması, genellikle gözle görülemeyen bir şey olarak kabul edilen "ruh" düşüncesini fotoğraf aracılığıyla tasvir etme arayışıdır. Sanatçı eserleri için, Afrika'daki "kötü ruh" inancından ve Doğu'daki mandala desenlerinden ilham almıştır (Armstrong, 2012). Sanatçı "Infinity" (Sonsuzluk) serisindeki eserlerini fotoğraf makinesinin sonsuza odaklanarak, odak dışındaki görüntüleri fotoğraflaması ile bulduğu soyut ya da figüratif görüntülerden oluşturmuştur. Bu görüntüleri bir araya getirip, çeşitli işlemlerden geçirerek manipüle eden sanatçı orijinal görüntüyü dönüştürerek yeni bir bağlamda okunmasına olanak verir. Aşırı bulanıklaştırarak, görüntülerin birleştiği kenarların kaybolmasını sağlar, böylece fotoğraflar sorunsuz ve bütünleşmiş görüntüler olarak algılanır. Sanatçı bu görüntülerle, kavrayışın ötesinde figürlerin olduğu tanımlanamaz, ancak yalnızca hafizada ya da rüyalarda var olabilecek bir dünya yarattığını ifade etmektedir. Renklerin meditatif etkisinin ön planda olduğu bu eserler aynı zamanda, her şeyin birbirine bağlı olduğu hissini verirken, gözün bu görüntüleri algılama güçlüğü yaşaması ve algılayamayışının yarattığı rahatsız edicilikten de yararlanmaktadır (Armstrong, t.y.).

\section{Görsel 14}

Bill Armstrong, Mandala \#454, 2003

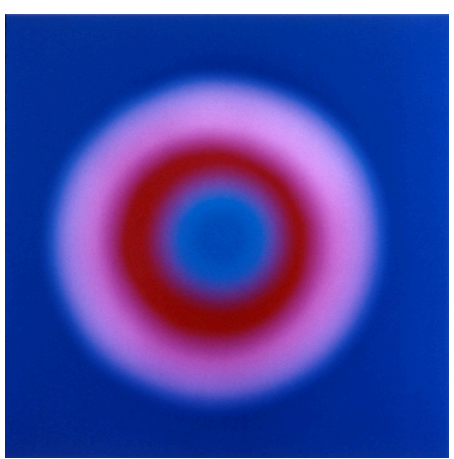

(Armstrong, 2003)

İranlı-Amerikalı sanatçı Y.Z. Kami’nin eserleri manevi aşkınlık ve sonsuzluğu akla getiren nitelikleri ile Mevlevi geleneğinden ilham almıştır. 2007 tarihli "Endless Prayer V” (Sonsuz Dua V) eserinde Mevlana'nın çeşitli mısralarını daireler ve spiraller oluşturacak şekilde bir araya getirmiştir. Eserdeki dönme hareketi etkisi akla hem Mevlevi ayinlerindeki dervişlerin dönüşünü hem de mandala desenlerini getirmektedir. Fiziksel olarak kendi etrafında dönmenin; ego ile bağlantıyı koparma, bireyin nefret dolu kendiliğinden arınması ve bireyin Tanrı ile bütünleşmesini sağladığı düşünülür (Godfrey, 2009, s. 23-25). 


\section{Görsel 15}

Endless Prayer V

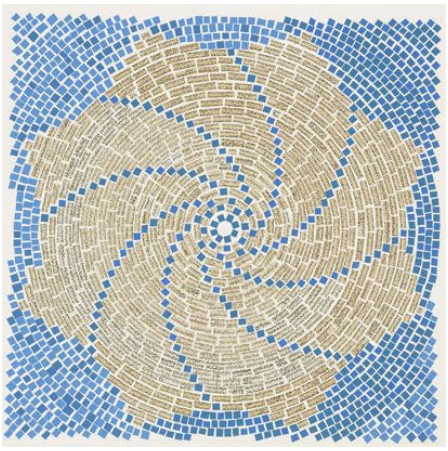

(Kami, 2007)

New York'lu sanatçı Amy Cheng, mandalalarında, ruhani etkiyi güçlendirmek için rengin psikolojik etkilerinden ve dairesel desenlerden yararlanmıştır. Güçlü 1şık-gölgelerin yarattığı derinlik, bilinmeyene giden sonsuz, bitmeyecekmiş gibi görünen bir yol hissi yaratır. Gül pencerelerindeki parlak 1ş1k etkisini hatırlatan işlerinde Cheng evrenin sonsuzluğunu ve onunla bütünleşmeyi görünür kılar.

\section{Görsel 16}

I Am The Cosmos

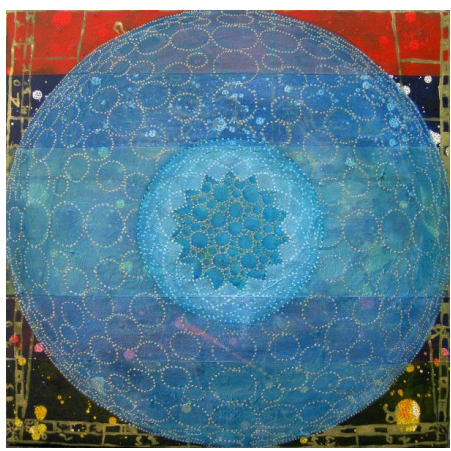

(Cheng, 2010)

Afrikal1-Amerikalı Ekspresyonist ressam Alma Woodsey Thomas, eserlerinde Bizans mozaikleri ve puantilist resimlerle bağlantı kuran dairesel kompozisyonlar kullanmıştır. Eserlerinde doğal yaşamdan renkleri ve bu renklerin birbiri üzerindeki etkilerini göstermiştir.

\section{Görsel 17}

Wind Dancing With Spring Flowers

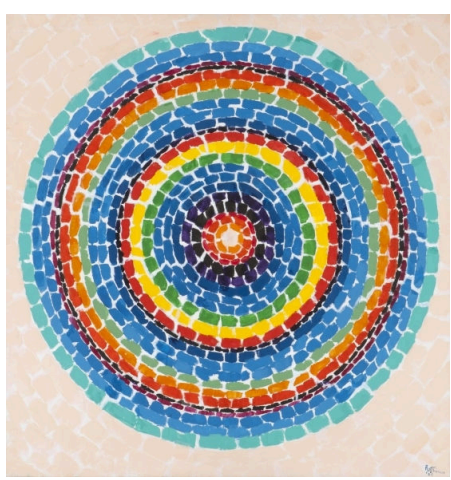

(Woodsey Thomas, 1969)

İngiliz sanatçı Damien Hirst mandala benzeri dairesel örüntüleri "Entomology" ve "Kaleidoscope” başlıklı serilerinde kullanmıştır. "Kaleidoscope" serisindeki eserlerinde, Hristiyan tasvir sanatlarında yeniden dirilişin, Antik Yunan'da ruhun sembolü olan kelebekleri kullanmıştır. Serideki eserlerin isimlerinde de Hristiyan ikonolojisine göndermeler vardır ve biçim olarak gül pencerelerini hatırlatırlar. 


\section{Görsel 18}

Limbo

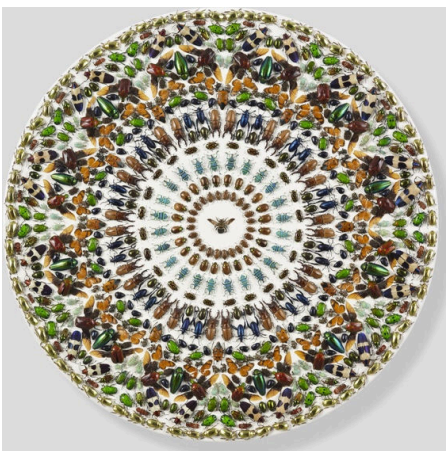

(Hirst, 2009)

Ölümle ilgili takıntılı olduğunu ifade eden Hirst için ölüm, çürüme ya da yok olma değil hayatın kutlanması ile ilgili bir durumdur. Kelebekler gibi böcekler de Hirst'ün ilgi alanındadır. Çünkü böcekler ölümün içinde var olan hayatın imgesini taşırlar ve hayatın kırılganlığını gösterirler. Ölü olsalar bile renklerini ve güzelliklerini muhafaza ettikleri için böcekler de kelebekler gibi Hirst'ün ilgi alanına girmişlerdir. Sanatçı “Entomology" serisine 2009'da başlamıştır. Her bir resim binlerce böcek türünün Hammerite ev tipi boyaya geometrik örüntüler biçiminde yerleştirilmesiyle oluşturulmuştur. Entomology serisindeki resimlerin başlıkları Dante'nin “İlahi Komedya”sından karakter ve olay isimlerinden alınmıştır (Hirst, 2013).

\section{Görsel 19}

Bug Blast

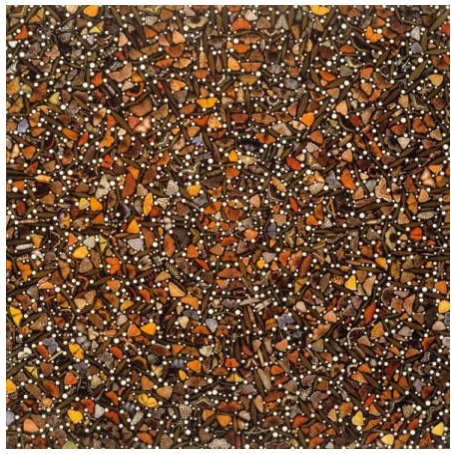

(Tomaselli, 1998)

Böcekler Fred Tomaselli'nin de sanatsal üretiminde yerini almıştır. "Bug Blast" (Böcek Patlaması) isimli eserindeki kompozisyon, merkezden çevreye doğru genişleyen dairelerle hipnotik bir mandalayı hatırlatır. Sanatçı bu eseri haplar, çeşitli psikotik maddeler, kelebek resimleri ve gerçek böcek parçaları ile oluşturmuştur. Eserdeki örüntüler ve renkler izleyici üzerinde uyuşturucu bir madde etkisindeymiş gibi halüsinojenik bir etki uyandırırlar (Fineberg, 2014, s. 495).

\section{Görsel 20}

Danmala

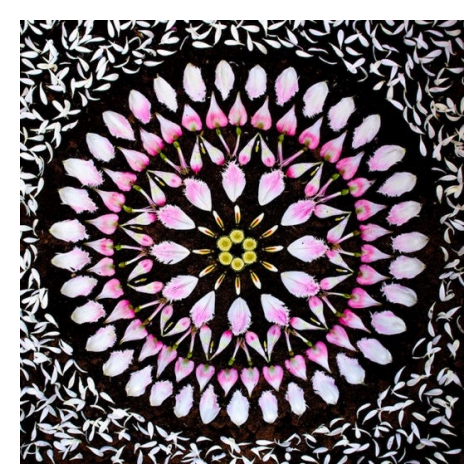

(Klein, 2014) 
İnsan ruhu ve doğa arasındaki uyum ve uyumsuzluğu görünür kılmak için doğal malzemelerle dairesel örüntüler yaratan bir diğer sanatçı Kathy Klein'dır. Sanatçı, "Dan” (Sanskritçe verici) ve "mala" (çelenk) kelimelerinin birleşimi olan "Danmala" adını verdiği işlerini üretmek için Deniz kabukları, tohumlar, çam kozalakları, taşlar ve çeşitli çiçekleri sanatsal materyal olarak kullanır. "Danmala" larını ürettikten sonra sanatçı onları izleyici ile karşılaşabilmeleri için doğada bir yere yerleştirir. Sanatçı tekrarlamalardan oluşan eserleri ile izleyicide ruhsal bir arınma ve rahatlama yaratmayı amaçlamaktadır (Noorata, 2014).

Doğadan materyaller kadar endüstriyel malzemeler de sanatçılara dairesel kompozisyonlarını üretirken malzeme çeşitliliği açısından çeşitlilik sağlamıştır. Londra merkezli sanatçı Leonardo Ulian bakır teller ve elektronik atıklardan oluşturduğu mandalalar ile teknolojinin insan hayatında spiritüelliğin yerini aldığına vurgu yapmayı amaçlamıștır. Eserlerine "Sacred Space" (Kutsal Alan) gibi bașlıklar vererek elektronik teknolojilerin, kendilerini daha iyi hissettikleri yeni bir mekân, yeni bir tür maneviyat olarak insan ruhunda dini yapıların görevini yerine getirdiğine gönderme yapmaktadır (Jobson, 2013). Cep telefonlarını kullanarak dairesel örüntüler oluşturan Rob Petit ise daha çok teknolojinin gelişimini hızlandırdığ çevre sorunlarına dikkat çekmektedir.

\section{Görsel 21}

Sacred Space

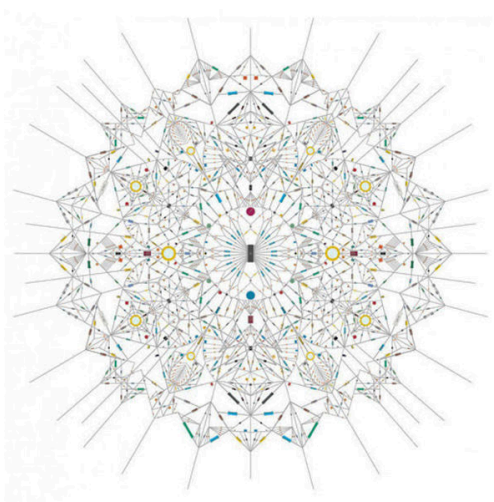

(Ulian, 2013)

Görsel 22

Cell Phone Mandala

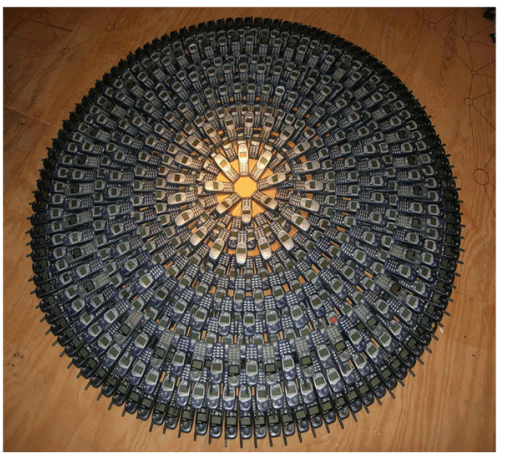

(Pettit, 2011)

Güney Koreli sanatçı Kim Sooja’nın ürettiği kavramsal işler, "Mandala: Chant for Auschwitz” başlığı ile Poznan Bienal'inde sergilenmiştir. Polonya'da bir İkinci el kıyafet dükkanından alınmış kıyafetlerin dairesel formda düzenlenmesiyle oluşturulmuş olan ve Tibetli rahiplerin söylediği ilahi sesleri ile de desteklenmiş olan enstalasyon Hitler' in Poznan Şato'sundaki eski ofisine yerleştirilmiştir. Sanatçı aynı zamanda mandala biçiminden oluşturduğu ses enstalasyonlarında da yararlanmaktadır. 2014 tarihli "Mandala: Zone of Zero" isimli işinde hedef tahtalarını da hatırlatan bir jukebox hoparlöründen Tibet, İslam ve Gregoryen ilahilerinin karışımından oluşmuş bir ses ortama yayılmaktadır. Mandala formu ile birlikte ilahilerin kullanımının izleyicide ruhani bir duygu uyandırırken, teknolojik bir aletin kullanılmış olması ile yabancılaşma duygusu da ön plana çıkmıştır (Yablonsky, 2003). 


\section{Görsel 23}

Mandala: Zone of Zero

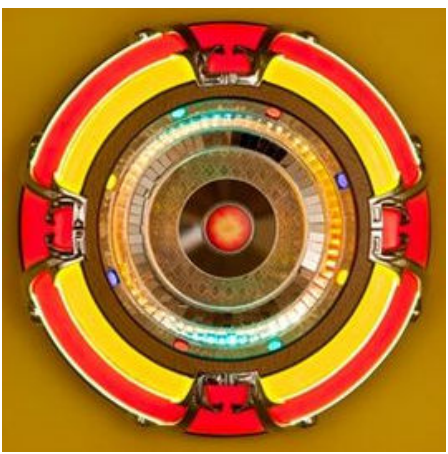

(Sooja, 2014)

16. yüzyıl tıp illüstrasyonlarından alınarak birbirine dijital olarak eklenmiş görüntülerle dairesel örüntüler oluşturan Aya Ben Ron, Batı tıbbının tedavi edici gücüne duyulan inancı sorgulamıştır. Sanatçının ürettiği kolajlarda kullandığı imgeler hastalıklı, sakat, bütünlüğü bozulmuş bedenlerden alınmıştır. Bu hastalıklı beden parçalarının sanatçının kompozisyonlarında parlak renkli dokulara dönüşmesi izleyici de yaşam-ölüm, hastalıksağlık vb. zıtlıkları besleyerek grotesk bir etki uyandırmaktadır. Sanatçı Batı tıbbına karşılık geleneksel tıbbın iyileştirici gücünü mandala deseninin ruhsal iyileştirici yönünden yararlanarak sorgulamıştır.

\section{Görsel 24}

Untitled

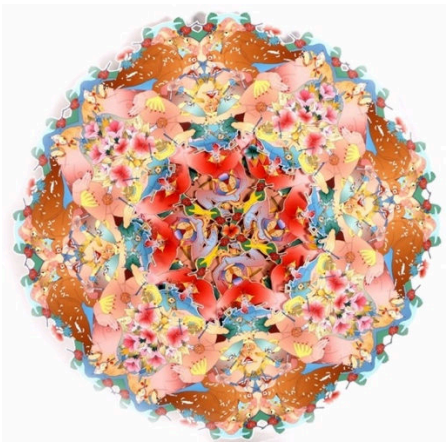

(Ron, 2000)

Jennifer Zackin kolektif bilincimizdeki "her yerde hazır ve nazır olan ordu” düşüncesini sorgulamak için Amerikan silahlı kuvvetlerine ait paraşütü Perululara özgü ponponlarla birlikte dokuyarak işlevini tersine çevirmiștir. "Hanaqpacha Intiq Sombran: 2004” başlıklı eserde kullanılan ponponlar için Cusco, Peru'daki Q'ero halkından yardım almıştır. Q’ero yerlilerinin inanç sisteminde paraşüt formu güneşi sembolize eder. Buradan yola çıkarak sanatçı dünyanın süper gücü konumundaki Amerika, And kültürü gelenekleri ve mandala desenlerinin sembolik işlevleri arasında bağlantı kurmuştur (Zackin, 2004a).

\section{Görsel 25}

Hanaqpacha Intiq Sombran

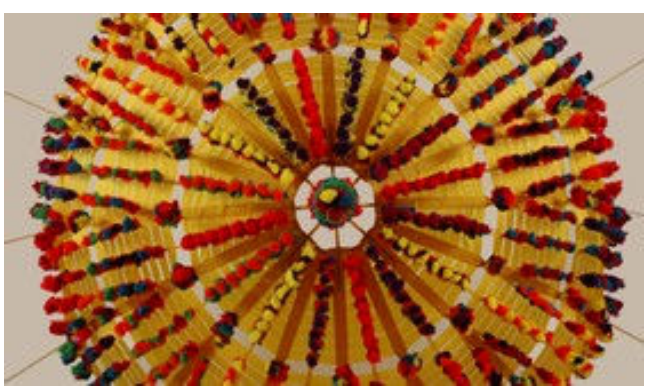

(Zackin, 2004b)

Mircea Cantor, politik görüșlerini dairesel kompozisyonlarla ileten bir başka sanatçıdır. 2010 tarihli "Holy Flowers" (Kutsal Çiçekler) işinde sanatçı, makineli silahları kaleydoskopik bir düzende yerleştirerek, dünyadaki 
küresel çatışmalara gönderme yapmıştır. Eserde silahların varlığının yarattığı tehlike ve ölüme yakınlık, çiçek benzeri mandala deseninin verdiği meditatif etki ile karışır.

\section{Görsel 26}

Holy Flowers

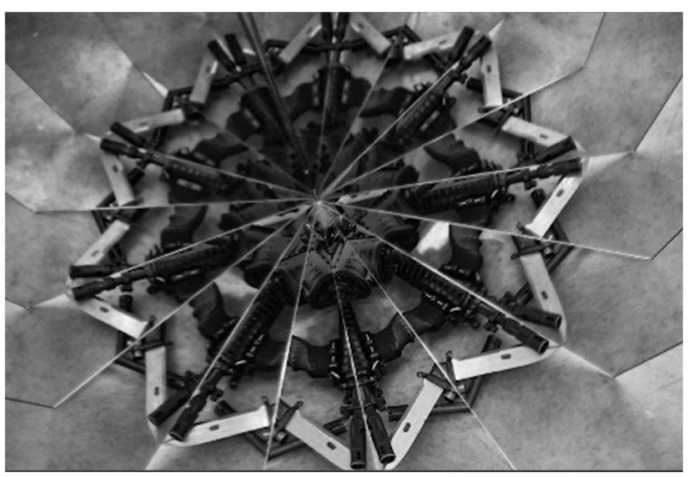

(Cantor, 2010)

1970'li yıllarda feminist sanatın gelişiminde rol oynayan sanatçılardan biri olan Miriam Schapiro yüksek sanat ile dekoratif sanatı birleştiren eserler üretmiştir. Pervane biçimi kadar yarım bir mandala formunu da andıran bu eserlerde kadınlara atfedilen malzemeleri ve teknikleri kullanmıştır (Smith, 1995, s. 462). Kapitone, nakış ve aplike gibi tekniklerle ürettiği bu eserlerde, yüksek sanat olarak görülen kolajın, anonim kadınların yarattığı zanaat ürünü kabul edilen el işleri ile bağlantısını sağlamak için "femmage" terimini kullanmıştır.

\section{Görsel 27}

Mother Russia

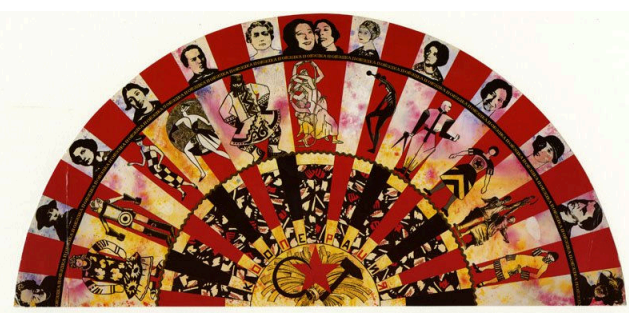

(Schapiro, 1994a)

Yarı dairesel bir kompozisyona sahip "Mother Russia” (Rusya Ana) isimli femmage eserinde Schapiro, feminist bir bakış açısıyla, Rus kadın sanatçılarını kullanmıştır. Eserde birbirinin izleyen kırmızı ve beyaz dikey çizgiler içeren en üst sırada sanatçının şapkalı kendi görüntüsünün yanı sıra; Sonia Delaunay, Antonia Sofronova, Olga Rozanova, Nina Simonovich Efimova ve Vera Muchkina gibi devrimci kadın sanatçıların ve rol modellerinin serigrafi görüntüleri bulunur. Bu sıranın hemen altında altın harflerle "poejdka" (yolculuk) kelimesinin yinelenmesinden oluşan dar bir satır bulunmaktadır. Bir alt satır, bu kadınlar tarafından yaratılan eserlerin reprodüksiyonlarını içerirken, "kooperaunia" (işbirliği) kelimesinin tekrarından oluşan bir sıradan sonra pervanenin merkezinde Rus bayrağının sembollerine atıfta bulunan orak, çekiç ve kırmızı yıldız figürleri bir demet buğdayın önüne yerleştirilmiştir (Schapiro, 1994b).

\section{Görsel 28}

Vaad Edilmemiş Topraklar

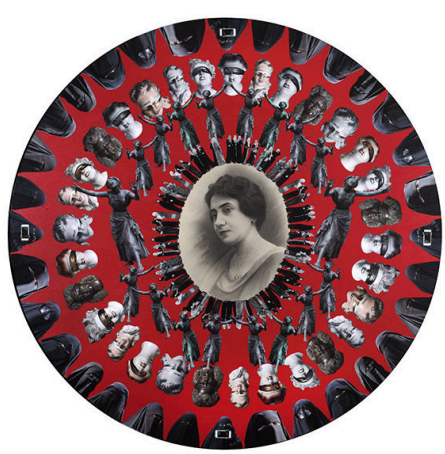

(Batıbeki, 2019) 
Türk sanatçı Kezban Arca Batıbeki de 2019 yılında gerçekleştirdiği "Vaad Edilmemiş Topraklar” başlıklı sergisinde kolaj tekniği ile dairesel kompozisyonlar üretmiştir. Feminist bir bakış açısının da dikkat çektiği sergideki kolajlarında, sanatçı, farklı kültürlerden kadın imgelerini gösteren fotoğrafları mülteci sorunu ve göç kavramı ile bağlantılı olarak kullanmıştır.

\section{Sonuç}

Semboller bilinç dışı düzeyde inanç sistemlerimizi, kültürümüzü dolayısıyla kimliğimizi yöneten ve yönlendiren biçimlerdir. Dairesel form bu sembollerin en arkaik ve birincil olanıdır. İlkel insanın çevresine bir daire çizerek kendisini dışardaki tehlikelerden koruyabileceği inancından hareketle, insanın dünyadaki en eski ayak izlerine bakıldığında dairesel form her aşamada karşımıza çıkar. Stonehenge ya da Göbeklitepe gibi antik dini yapıların planı ya da Müslümanların Ka'be 'yi tavafında olduğu gibi, insanın manevi bir seviyede dairesel formu Tanrı ile yakınlaşmada bir araç olarak kullandığı anlaşılmaktadır. Dairesel örüntülerin çeşitli kültürlerde gelişmesi dünyayı hareket ettiren ama kendisi hareketsiz kalan merkez inancı ile bağlantılıdır. Bu inanç, merkez sembolizminin gelişmesine kaynak olmuştur. Merkez sembolizmi, çeşitli dinlerin kutsal sanatlarında dairesel örüntülerden oluşan bir süsleme anlayışı ile görselleştirilmiştir. Bu görsellik ve dairesel örüntülerin spiritüel yönü, çağdaş sanatçılar için ruhsal olan ile maddesel olan arasındaki çatışmaya vurgu yapma aracı haline gelmiştir. Sanatçılar dairesel örüntüleri bir tür merkezileşme, iyileşme, kendine dönme aracı olarak kullandıkları gibi onlardan her tür bireysel idealizmlerini izleyiciye iletme amacıyla da yararlandıkları görülmektedir.

\section{Kaynakça}

Admin. (2021, Ekim 18). İsfahan Şah Camii kubbesi [Fotoğraf]. Media Nusa. https://trading.medianusa.co/

Ancient Art Podcast. (2017, Aralık 21). Eski bir Tibet mandala örneği [Fotoğraf]. Ancient Art Podcast. https://www.ancientartpodcast.org/blog/tibetan-mandalas-88/151-1996-mandala/

Archer, E. D. (1888). The timaeus of Plato. Cambridge University Press.

Armstrong, B. (2003). Mandala \#454 [Fotoğraf]. Clampart. https://clampart.com/2012/01/mandalas/\#thumbnails

Armstrong, B. (2012). Mandalas. Clampart. https://clampart.com/2012/01/mandalas/\#thumbnails

Armstrong, B. (t.y.). Bill Armstrong: Photographs from the infinity series. Billarmstrongphotography. https://www.billarmstrongphotography.com/statement

Arnheim, R. (2012). Görsel düşünme. (R. Öğgül, Çev.). Metis Yayınları.

Batıbeki, K. A. (2019). Vaad edilmemiş topraklar [Fotoğraf]. Hürriyet. https://www.hurriyet.com.tr/kelebek/ keyif/batibekinden-vaad-edilmemis-topraklar-41105280

Burckhardt, T. (2017). Doğu'da ve Batı'da kutsal sanat. (T. Uluç, Çev.). İnsan Yayınları.

Cairns, G. E. (1962). The philosophy and psyshology of the oriental mandala. Philosophy East and West,11(4), 219-229. https://doi.org/10.2307/1397024

Cantor, M. (2010). Holy flowers [Fotoğraf]. Artbasel. https://www.artbasel.com/catalog/artwork/54892/MirceaCantor-Holy-Flowers

Cheng, A. (2010). I am the Cosmos [Fotoğraf]. Amy Cheng. https://amychengstudio.com/portfolio/cosmos

Cooper, M. (2011, Eylül 26). Íslami geometrik desen detayı [Fotoğraf]. Wikimedia Commons. https://commons.wikimedia.org/wiki/File:Mosaic - Mosqu\%C3\%A9e de Paris.jpg

Doğanay, A. (2012). Tezyinat. TDV İslam Ansiklopedisi içinde. https://islamansiklopedisi.org.tr/tezyinat

Educating Humanity. (2012, Aralık 14). Çin Zodyak sistemi. [Fotoğraf]. http://www.educatinghumanity.com/ 2012/12/Ancient-Calendars-Mayans-Zodiac-Signs-End-Times-Astrology-Prediction.html

Ernst, M. (1969). Galaksinin doğuşu [Fotoğraf]. Wikiart. https://www.wikiart.org/en/max-ernst/birth-of-a-galaxy$\underline{1969}$

Fineberg, J. (2014). 1940’tan günümüze sanat. (S. Atay Eskier ve G. Erinç Yılmaz, Çev.). Karakalem Kitabevi Yayınlar1.

Fonseca Mata, H. C. (2019, Haziran 28). Aztek takvim taşı [Fotoğraf]. Wikimedia Commons. https://commons. wikimedia.org/wiki/File:Piedra_del_Sol_en_MNA.jpg

Gibson, C. (2017). Semboller nasıl okunur?. (C. Alpan, Çev.). Yem Yayın.

Godfrey, T. (2009). Painting today. Phaidon Press. 
Guenon, R. (2004). Âlemin hükümdarı: Dinlerde merkez sembolizmi. (İ. Taşpınar, Çev.). İnsan Yayınları.

Hirst, D. (2009). Limbo [Fotoğraf]. Damien Hirst. http://damienhirst.com/limbo

Hirst, D. (2013). Entomology cabinets and paintings, scalpel blade paintings and colour charts. Damien Hirst. http://damienhirst.com/exhibitions/solo/2013/white-cube-hong-kong

Jobson, C. (2013, Eylül 26). Sacred space: New technological mandalas by Leonardo Ulian. Colossal. https://www.thisiscolossal.com/2013/09/sacred-space-leonardo-ulian/

Jung, C. G. (2009). İnsan ve sembolleri. (A. N. Babaoğlu, Çev.). Okuyan Us Yayın.

Jung, C. G. (2015). Rüyalar. (A. Kayapalı, Çev.). Pinhan Yayıncılık.

Jung, C. G. (2017). Psikoloji ve din. (R. Karabey, Çev.). Okyanus Yayıncılık.

Jung, C. G. (2019, Temmuz 2). Jung'un mandala çizimi [Fotoğraf]. Envison Your Evolution. https://www.envisionyourevolution.com/analytical-psychology/create-your-own-mandala/2467/

Kami, Y. Z. (2007). Endless prayer $V$ [Fotoğraf]. Artpulse. http://artpulsemagazine.com/y-z-kami-endless-prayer

Kepler. (t.y.). Kepler'in Evren modeli [Fotoğraf]. The Scientific Revoution. https://revolutionscientific. weebly.com/discoveries.html?epik=dj0yJnU9NIBEdVJxa0w1anpvZkQ3cUtVbW9qRUFib0VIQzFRQlg mcD0wJm49V25UVGprT1ZKazJwTmtYaHNIb29tUSZ0PUFBQUFBR0FaaGtB

Klein, K. (2014). Danmala [Fotoğraf]. Kathyklein. http://kathyklein.org/danmala

Nasr, S. H. (2017). İslam sanatı ve maneviyatı. (A. Demirhan, Çev.). İnsan Yayınları.

Noorata, P. (2014, 19 Şubat). Beautiful mandalas made from nature by Kathy Klein. My Modern Met. https://mymodernmet.com/kathy-klein-danmala/

Okur Yazarım. (2016, Aralık 15). Malatya Ulu Camii kubbesi [Fotoğraf]. Okuryazarım. https://okuryazarim.com/ malatya-ulu-camii/

Osmanca, F. (2018, Ekim 30). Farkl kültürlerde Svastika sembolü [Fotoğraf]. Fosmanca. https://fosmanca.art/ serbest-kursu/bin-yillik-sembol-svastika-gamali-hac/

Ögel, S. (1994). Anadolu'nun Selçuklu çehresi. Akbank Yayınları.

Peker, A. U. (1998). Orta Çağ Anadolu mimarisinde anlam. Arkeoloji ve Sanat, 85, 29-39. https://www.academia.edu/6829711/Orta\%C3\%A7a\%C4\%9F_Anadolu_Sel\%C3\%A7uklu_Mimarisinde Anlam

Pettit, R. (2011). Cell phone mandala [Fotoğraf]. 4rtgallery. http://4rtgallery.blogspot.com/2014/04/cell-phoneart-by-rob-pettit.html

Riley, B. (1962). Blazel [Fotoğraf]. National Galleries Scotland. https://www.nationalgalleries.org/art-andartists/159569/blaze-1

Ron, A. B. (2000). Untitled [Fotoğraf]. Ayabenron. https://ayabenron.com/hanging/

Rudra Centre. (t.y.). Tantra yantra. Rudraksha-Ratna. https://www.rudraksha-ratna.com/articles/types-of-yantras

Schapiro, M. (1994a). Mother Russia [Fotoğraf]. Gallery 98. http://gallery.98bowery.com/2017/collaborationseries-1994-mother-russia/

Schapiro, M. (1994b). Mother Russia. The Art Story. https://www.theartstory.org/artist/schapiro-miriam/artworks/ \#pnt 7

Smith, E. L. (1995). Art today. Phaidon Press.

Sooja, K. (2014). Mandala: Zone of zero [Fotoğraf]. Kimsooja. http://www.kimsooja.com/projects_Mandala Zone of Zero Zacheta 2013.htm

Sutton, D. (2019). İslami tasarım geometrinin dehası. (U. İda, Çev.). A7 Kitap Yayıncılık.

Şenel, C. (2013). Yeni Eflatunculuk. TDV İslam Ansiklopedisi içinde. https://islamansiklopedisi.org.tr/yenieflatunculuk

The Met. (t.y.). Primary characteristics of Islamic geometric decoration. https://www.metmuseum.org/learn/ educators/curriculum-resources/art-of-the-islamic-world/unit-three/primary-characteristics-of-islamicgeometric-decoration 
Tomaselli, F. (1998). Bug blast [Fotoğraf]. Pinterest. https://tr.pinterest.com/pin/380554237232611087/

Ulian, L. (2013). Sacred space [Fotoğraf]. Artrabbit. https://www.artrabbit.com/events/leonardo-ulian-sacredspace

Wasatch Shutter Design. (2020, Ekim 23). Famous windows: The rose window of Notre Dame. https://wasatchshutter.com/famous-windows-the-rose-window-of-notre-dame/

Woodsey Thomas, A. (1969). Wind dancing with spring flowers [Fotoğraf]. Hoodmuseum. https://hoodmuseum.dartmouth.edu/news/2016/06/recent-acquisitions-alma-woodsey-thomas-winddancing-spring-flowers-1969

Workman, J. A. (2010, Ağustos 22). Notre Dame katedrali kuzey gül penceresi [Fotoğraf]. Wikimedia Commons. https://commons.wikimedia.org/wiki/File:North_rose_window of Notre-Dame_de_Paris,_Aug_2010.jpg

Worringer, W. (2017). Soyutlama ve özdeşleyim. (İ. Tunalı, Çev.). Hayalperest Yayınevi.

Yablonsky, L. (2003). Mandala: Zone of zero. Kimsooja. http://www.kimsooja.com/texts/yablonsky.html

Zackin, J. (2004a). Hanaqpacha Intiq Sombran. Jennifer Zackin. https://www.jenniferzackin.com/hanaqpachaintiq-sombran

Zackin, J. (2004b). Hanaqpacha intiq sombran [Fotoğraf]. Jenniferzackin. https://www.jenniferzackin.com/ hanaqpacha-intiq-sombran 